\title{
Allelic imbalance and microsatellite instability of the DCC gene in colorectal cancer in patients under the age of 35 using fluorescent DNA technology
}

\author{
R Chetty, R Naidoo, J Schneider
}

\begin{abstract}
Aim-To assess allelic imbalance and microsatellite instability in the region of the "deleted in colorectal cancer" (DCC) gene on chromosome 18q using fluorescent DNA technology in colorectal cancer in patients under the age of 35 .

Methods-Thirty two cases of colorectal cancer in patients under the age of 35 and with no family history of colon cancer were retrieved. DNA was extracted by standard methods, polymerase chain reaction (PCR) was performed using Cy5 labelled primers to microsatellite markers (D18S21, D18S34, and D18S58) in the DCC gene. The results were analysed using software attached to an automated DNA sequencer.
\end{abstract}

Results-The patients ranged in age from 17 to 35 years. Nineteen were women, all had left sided tumours (tumours distal to the splenic flexure). Twenty eight cases were either stage $C$ or $D$ (using the Astler Coller system). The informativity of the three markers were as follows: D18S21, 25 of $32(78.1 \%)$; D18S34, 18 of $32(56.25 \%)$; D18S58, 24 of 32 (75\%). Allelic imbalance for the markers, after excluding homozygous and microsatellite instability cases, was: D18S21, 31.8\%; D18S34, 11.7\%; and D18S58, $0 \%$. Nine cases showed allelic imbalance for both D18S21 and D18S34, yielding a combined allelic imbalance frequency of $39.1 \%$. Ten cases showed microsatellite instability in at least one marker, with microsatellite instability seen most commonly for D18S58. Three cases showed microsatellite instability for all three markers.

Conclusions-Approximately 39\% of cases showed allelic imbalance for D18S21 and D18S34 markers, while microsatellite instability was found in $31.25 \%$ of cases. This figure is higher than that encountered in sporadic colorectal cancer over the age of 50, suggesting a role for the DNA repair genes in the pathogenesis of these cancers occurring under the age of 35 .

(F Clin Pathol:Mol Pathol 1998;51:35-38)

Keywords: DCC gene; allelic imbalance; microsatellite instability; sporadic colorectal cancer; young patients

Colorectal cancer under the age of 35 is decidedly uncommon. It is assumed that such cases have a strong familial and/or genetic pathogenesis. In younger patients, colorectal tumours often accompany well defined syndromes such as hereditary non-polyposis colorectal cancer (HNPCC), Lynch syndrome, and familial adenomatosis polyposis (FAP) syndrome. The putative genes involved are the DNA repair and APC genes, respectively. We have identified a unique cohort of 32 cases of colorectal cancer in patients under the age of 35 with no apparent family history or association with any of the recognised predisposing syndromes. These cases were, therefore, classified as sporadic. As a starting point in the genetic analysis of these tumours, we undertook an evaluation of allelic imbalance and microsatellite instability of the "deleted in colorectal cancer" (DCC) gene in these patients.

\section{Materials and methods}

Thirty two colectomy cases of colorectal cancer were retrieved from the files of the departments of pathology, University of Natal School of Medicine and Stellenbosch University Medical School. All material was fixed in $10 \%$ buffered formal saline and processed in a standard manner. The patients' clinical notes were also accessed.

Histological sections were reviewed to confirm the grade and stage of the cancer. The Astler Coller staging system was used. Sections were then selected for DNA extraction. Normal (constitutional) DNA was obtained from the resection margins, while slides containing maximal tumour and minimal or no necrosis were selected for tumour DNA extraction. Contamination of tumour DNA by normal DNA was minimised by microdissecting the tumour from the section, and a minimum of $80 \%$ of the section consisted of tumour tissue.

DNA EXTRACTION

DNA was extracted from paraffin wax embedded tissue using a standard proteinase $\mathrm{K}$ and phenol/chloroform method. The presence of amplifiable DNA was verified by polymerase chain reaction (PCR) demonstration of the ubiquitous insulin gene.

\section{MICROSATELLITE ANALYSIS}

Cy5 labelled primers

The Cy5 labelled primers were purchased from Boehringer Mannheim, Penzberg, Germany. The microsatellite primers for the DCC gene used in this study were as follows:

D18S21 (5'-GTGGTTATTGCCTTGAA AAG-3'; 5'-GATGACATTTTCCCTCTAG$\left.3^{\prime}\right)$, these primers give PCR products of 
Table 1 Clinicopathological, allelic imbalance, and MSI features

\begin{tabular}{|c|c|c|c|c|c|c|c|}
\hline Case & Age & Sex & Grade & Stage & $D 18 S 21$ & D18S34 & D18S58 \\
\hline 1 & 34 & M & WD & C & AI & NAI & NAI \\
\hline 2 & 27 & $\mathrm{~F}$ & $M D$ & B & NAI & MSI & MSI \\
\hline 3 & 33 & M & $M D$ & C & NAI & NAI & NAI \\
\hline 4 & 20 & M & $\mathrm{MD}$ & C & NAI & $\mathrm{H}$ & NAI \\
\hline 5 & 35 & M & PD & B & MSI & $\mathrm{H}$ & NAI \\
\hline 6 & 34 & $\mathrm{~F}$ & PD & C & NAI & NAI & $\mathrm{H}$ \\
\hline 7 & 21 & M & $\mathrm{MD}$ & B & AI & NAI & NAI \\
\hline 8 & 28 & $M$ & PD & B & NAI & NAI & NAI \\
\hline 9 & 21 & $\mathrm{~F}$ & $\mathrm{MD}$ & B & MSI & MSI & $\mathrm{H}$ \\
\hline 10 & 29 & $\mathrm{~F}$ & PD & B & NAI & NAI & NAI \\
\hline 11 & 18 & M & PD & D & NAI & NAI & NAI \\
\hline 12 & 20 & $\mathrm{~F}$ & $M D$ & C & NAI & NAI & MSI \\
\hline 13 & 33 & $\mathrm{~F}$ & $\mathrm{MD}$ & B & $\mathrm{AI}$ & NAI & NAI \\
\hline 14 & 22 & $\mathrm{~F}$ & WD & $\mathrm{C}$ & $\mathrm{H}$ & MSI & $\mathrm{H}$ \\
\hline 15 & 25 & $\mathrm{~F}$ & $\mathrm{MD}$ & A & NAI & NAI & MSI \\
\hline 16 & 22 & $\mathrm{~F}$ & WD & B & AI & NAI & NAI \\
\hline 17 & 26 & M & PD & C & MSI & MSI & MSI \\
\hline 18 & 23 & $\mathrm{~F}$ & $\mathrm{MD}$ & $\mathrm{C}$ & $\mathrm{H}$ & NAI & NAI \\
\hline 19 & 23 & M & PD & $\mathrm{C}$ & NAI & $\mathrm{AI}$ & $\mathrm{H}$ \\
\hline 20 & 23 & M & PD & C & NAI & NAI & MSI \\
\hline 21 & 29 & $\mathrm{~F}$ & WD & D & NAI & $\mathrm{H}$ & NAI \\
\hline 22 & 17 & $\mathrm{~F}$ & $M D$ & C & AI & $\mathrm{H}$ & NAI \\
\hline 23 & 23 & $\mathrm{~F}$ & WD & B & $\mathrm{H}$ & $\mathrm{H}$ & NAI \\
\hline 24 & 29 & $\mathrm{~F}$ & PD & $\mathrm{C}$ & $\mathrm{AI}$ & NAI & NAI \\
\hline 25 & 28 & $\mathrm{~F}$ & WD & B & AI & $\mathrm{H}$ & NAI \\
\hline 26 & 24 & $M$ & PD & $\mathrm{C}$ & $\mathrm{H}$ & $\mathrm{H}$ & $\mathrm{H}$ \\
\hline 27 & 23 & M & PD & C & $\mathrm{H}$ & $\mathrm{H}$ & NAI \\
\hline 28 & 29 & $\mathrm{~F}$ & $M D$ & D & NAI & AI & NAI \\
\hline 29 & 21 & M & PD & C & NAI & $\mathrm{H}$ & NAI \\
\hline 30 & 28 & $\mathrm{~F}$ & $M D$ & B & MSI & MSI & MSI \\
\hline 31 & 25 & $\mathrm{~F}$ & WD & B & MSI & MSI & MSI \\
\hline 32 & 24 & $\mathrm{~F}$ & MD & B & NAI & NAI & $\mathrm{H}$ \\
\hline
\end{tabular}

WD, well differentiated; MD, moderately differentiated; PD, poorly differentiated; AI, loss of heterozygosity; NAI, no loss of heterozygosity; H, homozygous, uninformative case; MSI, microsatellite instability.
Automated DNA fragment analysis

The microsatellite PCR products were analysed using a $6 \%$ Longranger sequencing gel (FMC Bioproducts, Rockland, Maine, USA). Loss of heterozygosity and microsatellite instability were detected with the ALF Express DNA Automated Sequencer. The microsatellite analysis was performed under normal sequencing conditions of $1500 \mathrm{~V}, 60 \mathrm{~mA}$, and $15 \mathrm{~W}$ at a constant temperature of $55^{\circ} \mathrm{C}$. The data were analysed using the Fragment Manager software programme to detect peaks, peak heights, and peak areas.

\section{Sample preparation}

The microsatellite PCR products $(3 \mu \mathrm{l})$ were mixed with $3 \mu \mathrm{l}$ of STOP solution (blue dextran 2000, deionized formamide; Pharmacia Biotech, Uppsala, Sweden) and held on ice. The mixture was denatured at $96^{\circ} \mathrm{C}$ for three minutes in a Techne Progene thermocycler and held on ice before the samples were loaded on to the gel.

Preparation of size markers

Internal and external size markers were purchased from Pharmacia Biotech. The 100 and 300 base pair internal markers were used, while the $50-500$ base pair standard was used as the external size marker.

The computer software then generated electrophoretograms, with areas under the peaks calculated automatically.

ATTCTCTCTGG CCTGGCAAGAAT-3'), these primers generate a PCR product of 106-160 base pairs; D18S58 (5'-GCTCCCGGCTGGTT TT-3'; 5'-GCAGGAAATCGCAGGAACTT$3^{\prime}$ ), these primers give PCR products of 144-160 base pairs.

Primer sequences were obtained from Boland et al and Liu and colleagues. ${ }^{12}$ The first two primers amplify a TA repeat in an intron of DCC. The third primer (D18S58) is telomeric to the DCC gene and contains a CA dinucleotide repeat. ${ }^{3}$

\section{PCR reaction}

The reactions were carried out in $200 \mu$ l thin walled PCR tubes. The PCR Core Kit (Boehringer Mannheim) was used for this procedure. The kit consisted of: $10 \times$ reaction buffer (containing $1.5 \mathrm{mM} \mathrm{MgCl}_{2}$ ), dNTP mix, and Taq DNA polymerase. The Cy5 labelled primers (20 pmols) were used in the PCR in a total reaction volume of $25 \mu \mathrm{l}$, containing $5 \mu \mathrm{l}$ template DNA, $200 \mu \mathrm{M}$ dNTPs, $50 \mathrm{mM}$ PCR buffer containing $1.5 \mathrm{mM} \mathrm{MgCl}_{2}$, and $0.2 \mathrm{U}$ Taq DNA polymerase. The PCR amplification was performed using a Techne Progene thermocycler. The PCR reaction mixture was denatured initially at $95^{\circ} \mathrm{C}$ for five minutes. Thirty cycles were performed, consisting of one minute at $94^{\circ} \mathrm{C}$, 20 seconds at $58^{\circ} \mathrm{C}$, and 40 seconds at $72^{\circ} \mathrm{C}$. This was followed by a final extension step for 10 minutes at $72^{\circ} \mathrm{C}$. The PCR products were stored in a foil container at $4^{\circ} \mathrm{C}$ before analysis on a sequencing gel.

\section{Calculation of ratios for allelic imbalance}

Cases demonstrating homozygosity and/or microsatellite instability were excluded from the assessment of loss of heterozygosity/allelic imbalance. The allele ratios were calculated by the method suggested by Canzian and colleagues. ${ }^{4}$ Briefly, the peak areas were expressed as ratios as follows: (T2 $\times \mathrm{N} 1) /$ $(\mathrm{T} 1 \times \mathrm{N} 2)$, where $\mathrm{T} / \mathrm{N} 1$ and 2 are the first and second peaks of tumour and normal DNA, respectively. If the ratio was $<0.6$, then there was loss of the larger allele, and if the ratio was $>1.67$, then the smaller allele was lost. With the exclusion of homozygous cases and those showing microsatellite instability, there was a reduction in the number of informative cases. The allele imbalance frequency was then calculated using the following formula ${ }^{5}$ : $[\mathrm{AI} /(\mathrm{AI}+\mathrm{N})] \times 100 \%$; where $\mathrm{AI}$ is the number of cases with allelic imbalance and $\mathrm{N}$ is the number of cases not showing homozygosity or microsatellite instability.

Microsatellite instability

A difference in the electrophoretogram patterns (that is, the appearance of novel alleles) between normal and tumour DNA, was regarded as evidence of microsatellite instability for that marker. ${ }^{6}$ Tests were performed at least twice to confirm results.

\section{Results}

CLINICOPATHOLOGICAL FEATURES

The patients ranged in age from 17 to 35 years. Nineteen of the patients were female. None had a family history of colorectal cancer nor 


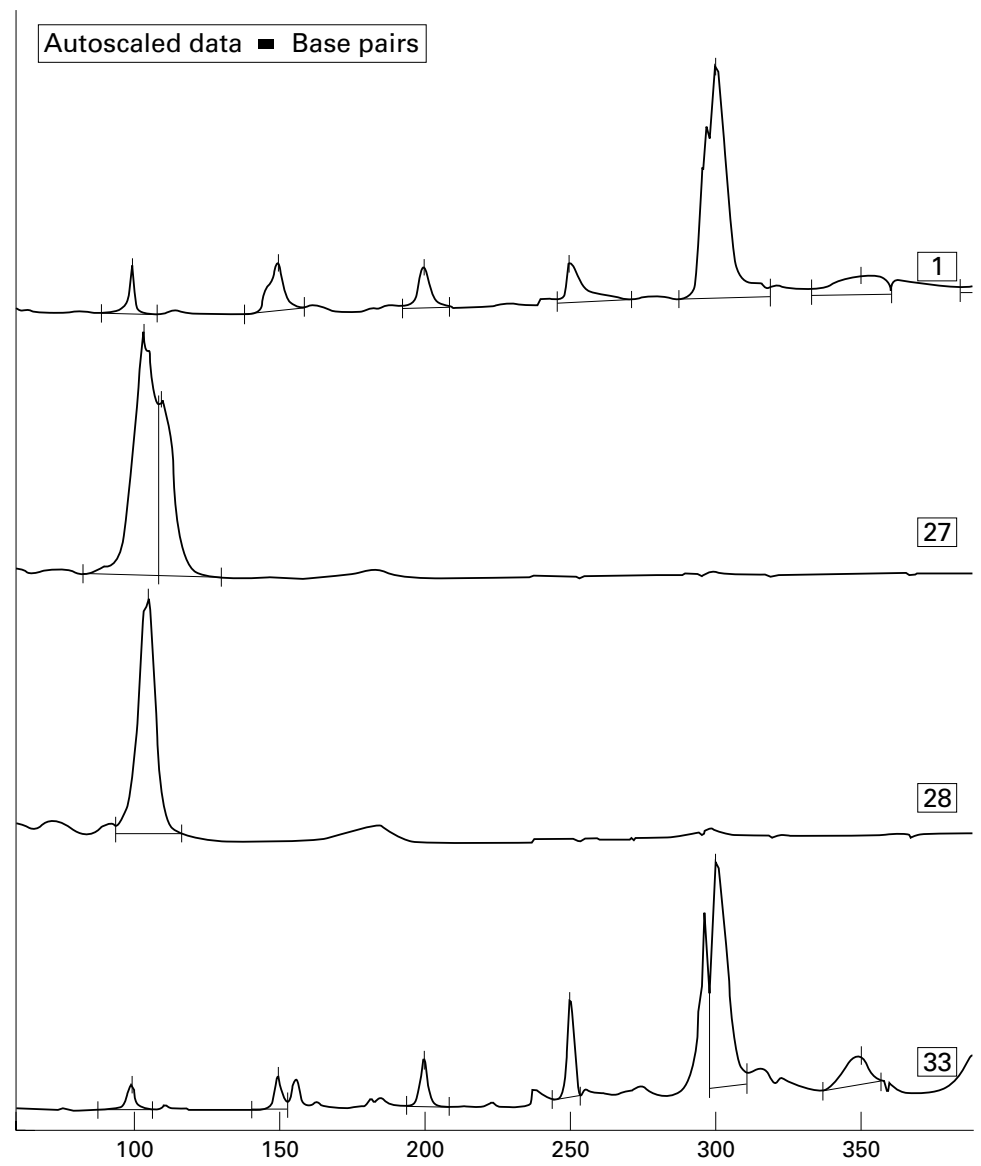

Figure 1 This is an example of a heterozygous, informative case (normal DNA, lane 27) showing loss of one allele (allelic imbalance) in the tumour (lane 28), for D18S34. The $x$-axis shows size in base pairs, while the $y$-axis reflects peak heights (not shown). The size range for the products is 103-119 base pairs. The upper trace of normal DNA shows two peaks of 104 and 110.3 base pairs. These constitute the two alleles. The second peak is not a stutter band because it is greater than two base pairs in size. The lower trace of tumour DNA clearly shows only one peak of 105.6 base pairs (within the accepted range for D18S34), implying loss of the second allele.

any cancers in other sites. All tumours were left sided, that is, located in the colorectal region distal to the splenic flexure. Seven cases were well differentiated, 13 were moderately differentiated, and 12 were poorly differentiated. Ten of the latter group contained a predominant signet ring cell population. Thirteen cases were stage $B, 15$ were stage $C$, three were stage $\mathrm{D}$, and only one case was stage A.

ANALYSIS OF DNA

Cases were deemed homozygous if the normal DNA yielded one peak on the electrophoretogram. These cases were, therefore, noninformative.

\section{Allelic imbalance}

The informativity for the three markers were as follows: D18S21, 78.1\% (25 cases); D18S34, $56.25 \%$ (18 cases); and D18S58, 75\% (24 cases) (table 1).

Frequency of allelic imbalance (excluding those cases showing either homozygosity or microsatellite instability) for these markers were: D18S21, seven of 22 (fig 1); D18S34, two of 17; and D18S58, no cases. Nine of 23 informative cases showed allelic imbalance for D18S21 and D18S34 (39.1\%).
Microsatellite instability

Ten of the $32(31.25 \%)$ cases showed microsatellite instability for at least one microsatellite marker (table 1 and fig 2). Three cases displayed microsatellite instability for all three markers. Two cases showed microsatellite instability for two markers, and five cases showed microsatellite instability for one marker only. Twenty two cases did not show microsatellite instability for any of the three markers used in this study.

\section{Discussion}

The use of semi and fully automated assessment of loss of heterozygosity and microsatellite instability or replication errors with fluorescent technology has been advocated by Cawkwell and colleagues. ${ }^{7}$ This technique has the advantages over conventional radioactive methods in that it allows the use of paraffin wax embedded tissue, it is less time consuming, and it introduces computer assisted objectivity. ${ }^{7}$ This technology can be adapted to analyse both allelic imbalance and microsatellite instability, two important mechanisms in the pathogenesis of colorectal cancer.

The phenomenon of microsatellite instability results from strand slippage due to defects in the DNA repair genes, which are meant to maintain the integrity of DNA during replication. Failure to do so results in the production of new alleles, which are detected by different peak patterns on electrophoretograms. Microsatellite instability is found in a wide range of malignancies, but is characteristic of colorectal tumours associated with the HNPCC syndrome. There are not many studies that have analysed allelic imbalance and microsatellite instability of the DCC gene in patients under 35 years of age. DCC has been investigated in sporadic colorectal cancer in patients usually over the age of 50 years. The DNA repair gene status of patients under 35 years has shown a statistically significant difference in the incidence of microsatellite instability in patients under 35, as compared with those over $35 .^{2}$

Allelic losses of chromosome $18 \mathrm{q}$ has been reported to occur in up to $70 \%$ of colorectal cancers. ${ }^{8}$ However, studies looking specifically at $18 \mathrm{q} 21$, the site of the DCC gene, show allelic imbalance or loss of heterozygosity ranging from $29 \%$ to $52 \% .^{5} 9$

The DCC gene is a tumour suppressor gene that encodes a cell adhesion molecule, and it is thought to be absent or reduced in late stage colorectal tumours. ${ }^{10}$ Indeed, allelic loss of chromosome $18 \mathrm{q}$ is thought to have prognostic ramifications. ${ }^{3}$ Stage II colorectal tumours with $18 \mathrm{q}$ losses behave like stage III tumours. In the analysis of our cases, allelic imbalance and microsatellite instability did not correlate with any clinicopathological parameter, but it should be noted that the numbers within the different stages were small. In this study, $39.1 \%$ of the cases demonstrated allelic imbalance for the two markers close to the DCC gene. This figure is within the range seen in sporadic colorectal cancer in patients over 50 years.

As described earlier, microsatellite instability is seen in $\sim 80 \%$ of colorectal tumours 


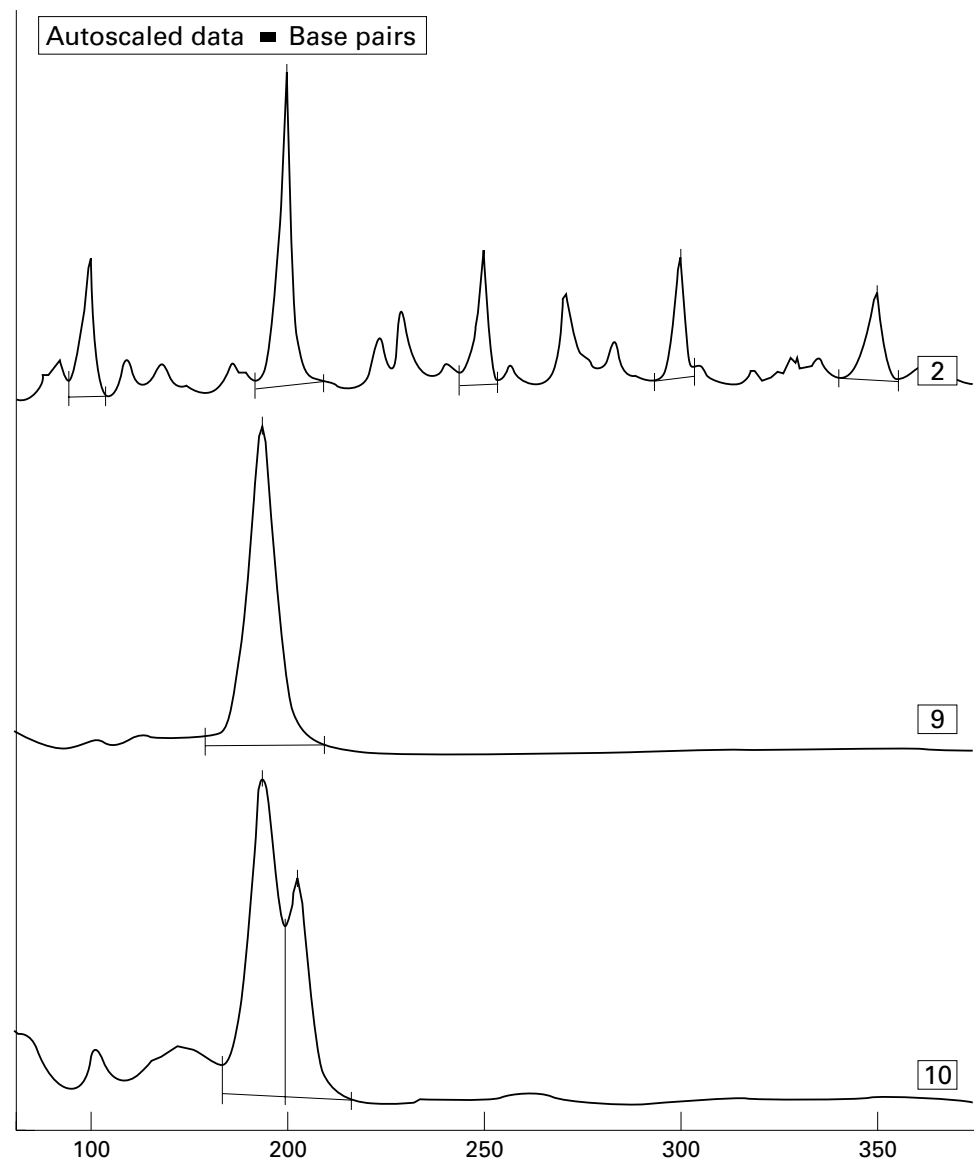

Figure 2 Electrophoretogram showing microsatellite instability for D18S21. The products for this marker should be within 150-210 base pairs in size. The upper trace (lane 9) shows only one peak of 193.5 base pairs. This is a homozygous case, and hence not informative for the assessment of allelic imbalance. However, the lower trace shows two peaks of 193.9 and 202.5 base pairs, respectively. The second peak is greater than two base pairs in size compared with the first peak and is, therefore, not a stutter band. It is a novel peak in the tumour compared with normal DNA and qualifies as an example of microsatellite instability. the situation lies with the ages of the patients in this study. Liu and colleagues found that $58 \%$ of patients under the age of 35 without the HNPCC syndrome showed microsatellite instability, many of which resulted from germline mutations in the DNA repair genes. ${ }^{2}$ Investigation of the status of these genes is underway in this group of patients.

This study has shown that loss of heterozygosity/allelic imbalance in the region of the DCC gene occurs in $39.1 \%$ of patients with colorectal cancer under the age of 35 , while microsatellite instability in this region is $31.25 \%$, indirectly indicating that DNA repair gene abnormalities are more frequent in colorectal cancer patients under the age of 35 compared with those over 50 years of age.

Grants from the University of Natal Research Fund and the Kennedy-Potts Cancer Research grant support RC and RN.

1 Boland CR, Sato J, Appelman HD, et al. Microallelotyping defines the sequence and tempo of allelic losses at tumour suppressor gene loci during colorectal cancer progression. Nat Med 1995;1:902-9.

2 Liu B, Farrington FM, Petersen GM, et al. Genetic instability occurs in the majority of young patients with colorectal cancer. Nat Med 1995;1:348-52.

3 Jen J, Kim H, Piantadosi S, et al. Allelic loss of chromosome $18 \mathrm{q}$ and prognosis in colorectal cancer. $N$ Engl f Med 1994;331:213-21.

4 Canzian F, Salovaara R, Hemminki A, et al. Semiautomated assessment of loss of heterozygosity and replication error in tumors. Cancer Res 1996;56:3331-7.

5 Cawkwell L, Lewis FA, Quirke P. Frequency of allele loss of DCC, p53, RB1, WT1, NF1, NM23 and APC/MCC in colorectal cancer assayed by fluorescent multiplex colorectal cancer assayed by fluorescent multiplex
polymerase chain reaction. Br f Cancer 1994;70:813-8.

6 Cawkwell L, Li D, Lewis FA, et al. Microsatellite instability in colorectal cancer: improved assessment using fluorescent polymerase chain reaction. Gastroenterology 1995;109: 465-71

7 Cawkwell L, Bell SM, Lewis FA, et al. Rapid detection of allele loss in colorectal tumours using microsatellites and fluorescent DNA technology. Br f Cancer 1993;67:1262-7.

8 Cho KR, Fearon ER. DCC: linking tumour suppressor genes and altered cell surface interactions in cancer? Eur $\mathcal{F}$ Cancer 1995;31A:1055-60.

9 Law DJ, Olschwang S, Monpezat J-P, et al. Concerted nonsyntenic allelic loss in human colorectal carcinoma. Science 1988;241:961-5.

associated with the HNPCC syndrome. ${ }^{11-17}$ However, only $15 \%$ of sporadic colorectal tumours demonstrate this phenomenon. ${ }^{17}$ In this study, we have shown that $31.25 \%$ of the cases demonstrated microsatellite instability at the three loci centromeric (two markers) and telomeric (one marker) to the DCC gene. This is indirect evidence that the DNA repair gene system and DNA polymerase $\delta$ are abnormal. The implications of this are manifold. Many of these cases could be undiagnosed cases of HNPCC, or they may result from de novo germline mutations in the DNA repair genes. This latter suggestion is not applicable to sporadic colorectal cancer in older patients, because germline mutations in the DNA mismatch repair genes were detected in only one of 10 sporadic colorectal tumours showing microsatellite instability. ${ }^{18}$ Perhaps the crux of
10 Kolodziej PA. DCC's function takes shape in the nervous system. Curr Opin Genet Dev 1997;7:87-92.

11 Aaltonen LA, Peltomaki P, Leach FS, et al. Clues to the pathogenesis of familial colorectal cancer. Science 1993; 260:812-6.

12 Ionov Y, Peinado MA, Malkhosyan S, et al. Ubiquitous somatic mutations in simple repeated sequences reveal a new mechanism for colonic carcinogenesis. Nature 1993; 363:558-61.

13 Thibodeau SN, Bren G, Schaid D. Microsatellite instability in cancer of the proximal colon. Science 1993;260:816-9.

14 Lothe RA, Peltomaki P, Meling GI, et al. Genomic instability in colorectal cancer: relationship to clinicopathological errors in benign and malignant tumors from hereditary nonpolyposis colorectal cancer patients. Cancer Res 1994; 54:1645-8.

16 Samowitz WS, Slattery ML, Kerber RA. Microsatellite instability in human colonic cancer is not a useful clinical indicator of familial colorectal cancer. Gastroenterology 1995;109:1765-71.

17 Peltomaki P. Microsatellite instability as an indicator of hereditary susceptibility to colon cancer. Gastroenterology 1995;109:2031-3.

18 Liu B, Nicolaides NC, Markowitz S, et al. Mismatch repair gene defects in sporadic colorectal cancers with microsatellite instability. Nat Genet 1995;9:48-55. variables and family history. Cancer Res 1993;53:5849-52.

15 Aartonen LA Peltomaki P, Mecklin J-P, et al R.5849-52. 